\title{
TÜRKIYY'DE NÜFUSUN YETERLİ VE DENGELİ BESLENMESİ AÇISINDAN HAYVANSAL GIDA ARZ VE TALEBİNINN DEĞERLENDİRİLMESİ
}

\author{
Betül Gürer* \\ Niğde Ömer Halisdemir Üniversitesi, Tarım Bilimleri ve Teknolojileri Fakültesi, Niğde, Türkiye
}

Geliş / Received: 06.05.2021; Kabul / Accepted: 26.11.2021; Online bask1 / Published online: 15.12.2021

Gürer, B. (2021). Türkiye'de nüfusun yeterli ve dengeli beslenmesi açısından hayvansal gida arz ve talebinin değerlendirilmesi. GIDA (2021) 46 (6) 1450-1466 doi: 10.15237/gida.GD21083

Gürer, B. (2021). Evaluation of the supply and demand for animal products in terms of sufficient and balanced nutrition in Turkey. GIDA (2021) 46 (6) 1450-1466 doi: 10.15237/gida.GD21083

\section{ÖZ}

Çalışmada, bireylerin yeterli ve dengeli beslenebilmesi için uzmanlar tarafından yaş ve cinsiyete göre önerilen günlük besin tüketim referans miktarlarını tükettikleri varsayıldığında, Türkiye'de nüfusun hayvansal ürünler arz ihtiyacı ve yeterliliğinin değerlendirilmesi amaçlanmıştır. Çalışma sonucunda, Türkiye'de hayvancllı sektörüne yönelik destekleme kalemleri ve miktarındaki artış üretime olumlu yansımış, ancak üretimdeki artışın toplumun yeterli ve dengeli beslenmesini temin edecek boyutta olmadığı görülmüştür. 2019 yllında, Türkiye'de nüfusun yeterli ve dengeli beslenebilmesi için hayvansal gıda arz ihtiyacı kişi başı yıllık kırmızı ettavuk eti için $31.39 \mathrm{~kg}$, balık için $27.22 \mathrm{~kg}$, yumurta için $13.54 \mathrm{~kg}$ ve süt ve süt ürünlerinde $252.99 \mathrm{~kg}$ olarak hesaplanmıştır. Ancak nüfusun mevcut beslenme kompozisyonu dikkate alındığında süt ve süt ürünleri hariç diğer hayvansal ürünler arzının ihtiyacın altında olduğu görülmüştür. Bu nedenle, nüfusun gereksinimine uygun hayvansal ürünler arzının ve erişilebilirliğinin sağlanması, toplumun beslenme sorunlarını dikkate alan üretim planlaması ile hayvansal ürünler arz zincirine yönelik bütüncül uzun vadeli tedbirlerin birlikte ele alınmass ile mümkündür.

Anahtar kelimeler: Hayvansal ürünler, gıdanın bulunabilirliği, hayvansal ürün tüketimi, tarım politikaları, beslenme yapis1

\section{EVALUATION OF THE SUPPLY AND DEMAND FOR ANIMAL PRODUCTS IN TERMS OF SUFFICIENT AND BALANCED NUTRITION IN TURKEY}

\begin{abstract}
This study was aimed to evaluate the supply and adequacy of animal products in Turkey supposing that individuals consume recommended dietary reference values by age and gender. As a result, the increase in livestock supports in Turkey had a positive effect on the production, but this increase was not sufficient to ensure for nutritionally adequate diet of the society. In 2019, the animal products supply requirement in Turkey was calculated as $31.39 \mathrm{~kg}$ for red meat-chicken meat, $27.22 \mathrm{~kg}$ for fish, $13.54 \mathrm{~kg}$ for eggs and $252.99 \mathrm{~kg}$ for milk and dairy products per capita. However, considering the current dietary composition of the population, the supplies of animal products, excluding milk and dairy products, were below the requirement. Ensuring sufficient supply and accessibility of animal products is possible with the production planning considering the nutritional problems of the society and holistic and long-term measures for supply chain of animal products.

Key words: Animal products, food availability, animal products consumption, agricultural policies, nutritional structure
\end{abstract}

*Yazışmalardan sorumlu yazar / Corresponding author

1):bgurer@ohu.edu.tr,

(ग): (+90) 3882253045

且: (+90) 3882254441

Betül Gürer; ORCID no: 0000-0002-9358-023X 


\section{GİRİ̧̧}

G1da talebinin hem miktar hem de besin değeri açısından yeterli şekilde karşılanması durumu özellikle Türkiye gibi gelişmekte olan birçok ülke için tarım ve gida politikalarının öncelikli hedefleri arasında yer almaktadır (SBB, 2019). Ulusların ve onu oluşturan bireylerin fiziksel, zihinsel ve ruhsal yönden sağlıklı ve güçlü olarak yaşamasında, ekonomik ve sosyal yönden gelişmesinde, refah düzeyinin yükselmesinde beslenme insanın temel gereksinimlerinden birisi belki de en önemlisidir (Yağmur ve Güneş, 2010).

Dünya nüfusunun giderek artması ile artan gida talebine karşıllk üretimin ülkeler ve bölgeler arasında dengesiz dağılımı sonucu dünyanın çeşitli bölgelerinde insanlar açlık tehlikesi ile karş1 karşıyadır. Bugün dünyada 820 milyondan fazla insan kronik açlık çekmektedir (FAO, 2020a). Bir diğer rahatsız edici gerçek ise dünyada yaklaşık 2 milyar insanın orta veya şiddetli seviyede gıda güvencesizliği içerisinde olduğudur (FAO, 2020a). Besleyici ve yeterli gidaya düzenli erişimi sağlayamayan kişilerin kötü beslenme ve sağlıklarının bozulması riski artmaktadır.

$\mathrm{Bu}$ kapsamda, sorunun çözümünde hem ekonomik kalkınmanın hem de ülke nüfusuna yüksek besin değeri sağlaması açısından hayvancilık sektörünün kilit bir role sahip olduğu söylenebilir. Dünya Sağlık Örgütü (WHO) verilerine göre sağlıklı bir insanın vücut ağırlığının her kilogramı için günde 1 gram protein tüketmesi ve bunun da \%42'sinin hayvansal kökenli olması gerekmektedir (TIGGEM, 2020). Diğer yandan protein tüketiminde hayvansal kaynaklı gidaların katkısı dünya genelinde $\% 39.89$, AB'de $\% 58.30$ ve ABD'de ise $\% 64.60$ olduğu tahmin edilmektedir (FAO, 2020b). Gelişmekte olan ülkelerin nüfus ve gelir artışı ile birlikte kişi başı hayvansal protein tüketimleri artış eğilimindedir.

Türkiye'de 2000'li y1llardan itibaren hayvansal üretime yönelik uygulanan politikaların etkisiyle son yillarda hayvansal üretimdeki azalış durdurulabilmiş olsa da Türkiye'deki hayvansal g1da üretim seviyesinin nüfusun yeterli ve dengeli beslenme açısından arzu edilen düzeyde olup olmadığ incelenmesi gerekmektedir.
Bu açıdan literatürde Türkiye'de farklı hayvansal ürünlerin arz ve talebine yönelik çalışmalar bulunmaktadır. Bu çalışmalar arasında Türkiye'de kırmızı et arzı, sürdürülebilirliği ve sorunlarına yönelik (Öztornac1, 2013; Tosun, 2016; Saygin ve Demirbaş, 2017) ulusal düzeyde çalışmalar bulunmaktadır. Bununla birlikte Gürer (2013) Türkiye'de hayvansal ürünlerde gıda güvencesinin durumunu bulunabilirlik, erişilebilirlik, istikrar ve gıda güvenilirliği unsurları bakımından incelemiştir Ayrıca il veya bölge düzeyinde ise kırmızı et, tavuk eti, balık, süt ve yumurta gibi hayvansal ürünlerde bireylerin veya hanelerin tüketim yapısının araştırılmasına yönelik çok sayıda çalışma mevcuttur (Hatırlı ve ark., 2007; Sayg1 ve ark., 2014; Alev, 2015; Terin ve ark., 2016; Türkmen ve ark., 2016; Güngör ve Ceyhun, 2017; Karakaya ve Kızıloğlu, 2018; Saygın ve Demirbaş, 2018; Can, 2019 ; Doğan, 2019; Özyürek ve ark., 2019; Aytop ve Işık, 2020;).

Ancak literatürde Türkiye'de nüfusun yaş ve cinsiyet dağılımı dikkate alınarak yeterli ve dengeli beslenebilme için hayvansal ürün arzı ihtiyacının değerlendirilmesine yönelik çalışmaya rastlanılmamıştır. $\mathrm{Bu}$ kapsamda çalışmada öncelikli olarak, hayvansal ürün arzının mevcut durumunun ve gelişiminin kişi başı gıdanın bulunabilirliğine göre incelenmesi amaçlanmıştır. Çalısmanın bir diğer amacı ise Türkiye'de nüfusun beslenme yapis1 ve hayvansal ürün tüketim durumlarının ortaya koyularak hayvansal ürün talebini etkileyen başlıca unsurların incelenmesidir. Son olarak ise nüfusun yaş ve cinsiyet dağılımı dikkate alınarak yeterli ve dengeli beslenme için önerilen günlük besin tüketim referans miktarlarını tükettikleri varsayıldığında, 2019 yılı ve 2025 yılı için hayvansal ürünler arz ihtiyacının ve yeterliliğinin değerlendirilmesi amaçlanmıştır.

\section{MATERYAL VE YÖNTEM}

Çalışmanın ana materyalini hayvansal ürünler ve makroekonomik değişkenlere ait ulusal ve uluslararası veri tabanlarından elde edilen zaman serisi verileri oluşturmaktadır. Bu amaçla çalışma için gerekli veriler Türkiye İstatistik Kurumu (TÜIK), Birleşmiş Milletler Gıda ve Tarım 
Örgütü (FAO), Tarım ve Ormancllık Bakanlı̆̆1, Uluslararas1 Ticaret Merkezi (ITC) veri tabanlarından elde edilmiştir.

Hayvansal ürünlerde kişi başı bulunabilirlik FAO (2002) tarafindan benimsenen, gida arz1 yaklaşımına göre hesaplanmıştır. Buna göre gıdanın bulunabilirliği kavramı, bir ülkede tüketilmeye hazır bulunan gida miktarı ile ölçülmekte olup eşitlik (2.1)'de formüle edilmiştir. Elde edilen sonuçlar, ilgili yllın nüfusuna bölünerek hayvansal ürünlerde kişi başı bulunabilirlik düzeyleri elde edilmiştir.

$$
\begin{aligned}
& \text { Gldanın Bulunabilirliğ } i=\left(\begin{array}{c}
\text { Üretim } \\
\text { Ithalat } \\
\text { Başlangıc stokları }
\end{array}\right)- \\
& \left(\begin{array}{c}
\text { Gıda dışı kullanım } \\
\text { İracat } \\
\text { Yıl sonu stokları }
\end{array}\right)
\end{aligned}
$$

Türkiye'de hayvansal ürün kişi bașı gida arzının yıllık ortalama artıș hızının hesaplanmasında ise FAO (2020b) veri tabanindan elde edilen kalori (kcal) cinsinden nüfusun günlük gida arz1 miktarları üçer yıllık ortalamalarına göre iki dönem arasındaki ortalama yıllık artış hızları hesaplanmıştır (Gürer, 2013). Aynı yöntem nüfus artış hızı hesaplanması için de kullanılmışır. Artış hızının hesaplanmasında izlenen yöntem (2.2)'de gösterilmektedir.

$P_{n}=P_{0} \times(1+r)^{n}$

Formülde $P_{n}$ son yll değerini, $P_{o}$ ilk yıl değerini, $n$ dönem süresini ve $r$ yıllık artış hızını ifade etmektedir.

Türkiye'de hayvansal ürün ihtiyacının tahmin edilmesinde Sağlık Bakanlığı (2019) tarafindan yayınlanan Türkiye Beslenme Rehberi (2015)'nden faydalanılarak yaş ve cinsiyete göre besin tüketim referans miktarları çıkarılmıștır (Çizelge 1). Daha sonra yaş ve cinsiyete göre nüfusun hayvansal ürün gereksinim miktarlar1 ise TÜİK (2020a) tarafindan hesaplanan 2019 yilı ve 2025 yilı nüfus projeksiyonlarına dayanarak ayrı ayrı hesaplanmıştır.

Çizelge 1. Hayvansal ürünler yaş ve cinsiyete göre önerilen kişi başı günlük porsiyon miktarlar1 ${ }^{1}$ Table 1. Recommended daily portion amounts of animal products by age and gender

\begin{tabular}{lcccc}
\hline $\begin{array}{l}\text { Yas gruplar } \\
\text { Age groups }\end{array}$ & $\begin{array}{c}\text { Kirmiz1 et ve tavuk } \\
\text { Red meat and chicken meat }\end{array}$ & $\begin{array}{c}\text { Yumurta } \\
\text { Eggs }\end{array}$ & $\begin{array}{c}\text { Balik } \\
\text { Fish }\end{array}$ & $\begin{array}{c}\text { Süt ve süt ürünleri } \\
\text { Milk and dairy products }\end{array}$ \\
\hline $0-4$ & 0,330 & 0,500 & 0,119 & $\begin{array}{c}\mathrm{E}^{2} M^{2}: 2,500 ; \\
\mathrm{K}^{2} F^{2}: 2.000\end{array}$ \\
\hline $5-9$ & 0,750 & 0,500 & 0,214 & 2,750 \\
\hline $10-14$ & 0,750 & 0,500 & 0,286 & 3,000 \\
\hline $15-19$ & $\begin{array}{c}\mathrm{E}^{2} M^{2}: 1,250 ; \\
\mathrm{K}^{2} F^{2}: 1.000\end{array}$ & 0,500 & 0,286 & 3,000 \\
\hline $20-49$ & 0,750 & 0,357 & 0,286 & 3,000 \\
\hline $50-69$ & 0,750 & 0,357 & 0,286 & 3,000 \\
\hline 70 yaş ve üzeri & 0,750 & 0,357 & 0,286 & 3,000 \\
70 and above & & & &
\end{tabular}

${ }^{1} 1$ standart porsiyon kırmızı et ve tavuk eti için 100 gr kemiksiz çiğ ete, yumurta için 100 gr (2 yumurta), balık için 250-300 gr ayıklanmamış çiğ balığa ve süt ve süt ürünleri için $240 \mathrm{ml}$ süte eşdeğer kabul edilmiştir.

11 standard portion was equivalent to $100 \mathrm{~g}$ of boneless raw meat for red meat and chicken, $100 \mathrm{~g}$ (2 eggs) for eggs, 250-300 g of unsorted raw fish for fish, and $240 \mathrm{ml}$ of mille for dairy products.

${ }^{2} \mathrm{E}$ : Erkek; K: Kadın

${ }^{2}$ M: Male; F:Female

Kaynak: Sağlık Bakanlığı (2019)'dan derlenmiştir.

Source: Derived from Ministry of Health (2019) 


\section{BULGULAR VE TARTIŞMA}

\section{Türkiye'de Hayvansal Gıda Üretim ve Dı̧̧} Ticareti

Hayvansal gida arzı, hayvansal gıda üretimi, stoklar ve dış ticareti tarafından belirlenmektedir. Bu kapsamda hayvansal gida üretimi kapsamında koyun eti, dana eti, tavuk eti, su ürünleri, süt ve yumurta üretiminin son 20 ylllık gelişimi Şekil 1'de verilmektedir. Türkiye'de toplam et üretimi içerisinde kırmızı et üretiminin pay1 \%36 olup, geri kalanını tavuk eti oluşturmaktadır. Türkiye'de toplam kırmızı et üretimi içerisinde dana etinin pay1 2010 yllinda \%82.0'den 2019 yllinda \% \%0.8'e ulaşmışır. 2010 yllında 135.7 bin ton olan koyun eti üretimi 2019 yllında \%19 azalarak 109.4 bin ton olarak gerçekleşmiştir. Aynı dönemde dana eti üretimi ise $\% 73.9$ oranında artarak 618.6 bin tondan 1 milyon 75.5 bin tona yükselmiştir. 20002019 yllları arasında Türkiye'de tavuk eti üretimi 3.3 kat artmıştır. Aynı dönemde süt üretimi $\% 134.4$ ve yumurta üretimi ise $\% 47.3$ oranında artmıştır. Su ürünleri üretimi ise ilgili dönemde \%43.6 oranında artmıştır. Türkiye'de son yıllarda yetiştiricilik (kültür balıkçıllı̆ı) ile elde edilen balık üretiminde ciddi bir artışın olduğu göz önünde bulundurulmalıdır. Nitekim 2000 yilında toplam su ürünleri içerisindeki yetiştiricilik ile elde edilen balık üretiminin pay1 \%13.5'den (79 bin ton) 2019 yllinda \%44.6'ya (373 bin ton) yükselmiştir (TÜIK, 2020b).

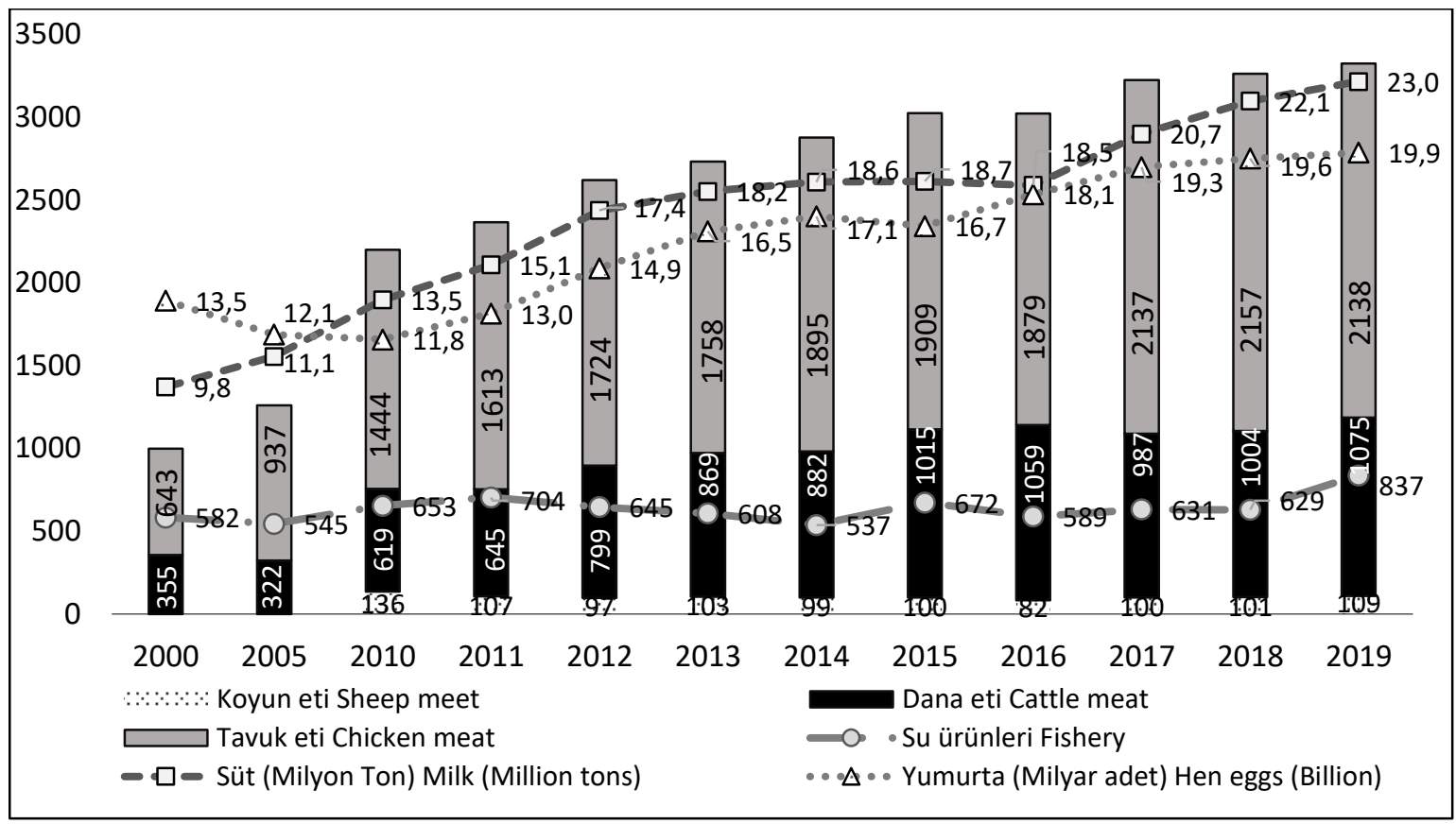

Şekil 1. Türkiye'de Hayvansal Ürünler Üretimi ( Bin Ton)

Figure 1. Livestock products in Turkey (Thousand Tons)

Kaynak Source: TÜIK (2020b).

Şekil 2'de Türkiye'de hayvansal ürünler dış ticaretinin gelişimi verilmektedir. Türkiye'de hayvansal ürünler içerisinde en çok diş ticarete konu olan ürünler arasinda kümes hayvanları eti ve sakatatı ihracatı ile su ürünleri ihracatı yer almaktadır. Kümes hayvanları ithalatı ise et ve yumurta tavukçuluğunda damızlık temini nedeniyle yapilmaktadır. Bununla birlikte 2010 yılından itibaren sığır eti ithalatına izin verilmesi ile birlikte bu yıldan itibaren yurtiçi talebe göre düşük miktarda sığır eti ithalatı yapılmaktadır.

Kişi Başı Hayvansal Ürün Arzı Bulunabilirliği Hayvansal gidaların bulunabilirliği konusu hayvansal gıda arzı ile ilgilidir. Bununla birlikte, hayvansal ürünler arzının talebi karşılama düzeyinin daha net anlaşılabilmesi için kişi başı hayvansal ürünler arzı gelişiminin incelenmesi 


\section{B. Gürer}

önemlidir. Türkiye'de nüfus artışına karşılık yeterli ve dengeli beslenmeyi sağlayacak miktarda gida arzının temin edilmesi gereklidir. Bu nedenle beşer yıllık dönemler halinde kişi başı hayvansal ürün arzının ortalama yıllık artış hızları hesaplanarak Şekil 3'te verilmiştir. Gıda arzı, kalori cinsinden hesaplanmış günlük kişi baş1 hayvansal ürün arzındaki artış hızını ifade etmekte olup toplam hayvansal ürünler, büyükbaş kırmızı et, küçükbaş kırmızı et, tavuk eti, balık, yumurta ve süt için hesaplanmıştır. Buna göre, 2001-2003 ile 2006-2008 yılları arasında kişi başı hayvansal ürünler gıda arzı yıllık ortalama \%2.69 oranında artmıştır. 2000’li yılların ortalarından itibaren gerek hayvancillğa yönelik yeni destekleme politikalarının uygulamaya konulması gerekse sığır eti ithalatt ile birlikte hayvansal ürünlerde kişi başı gıda arzı artış1 \%4.13 oranında gerçekleşmiştir. 2011-2013 ile 2016-2018 y1llar1 aras1 dönemde ise kişi başı yıllık hayvansal gıda arzındaki artış hızı bir önceki döneme göre yavaşlayarak y1llık ortalama $\% 1.90$ olarak gerçekleşmiştir. $\mathrm{Bu}$ azalışta büyükbaş kırmızı et, tavuk eti ve süt arzı artış hızının bir önceki döneme göre düşmesinin etkisi olduğu söylenebilir.

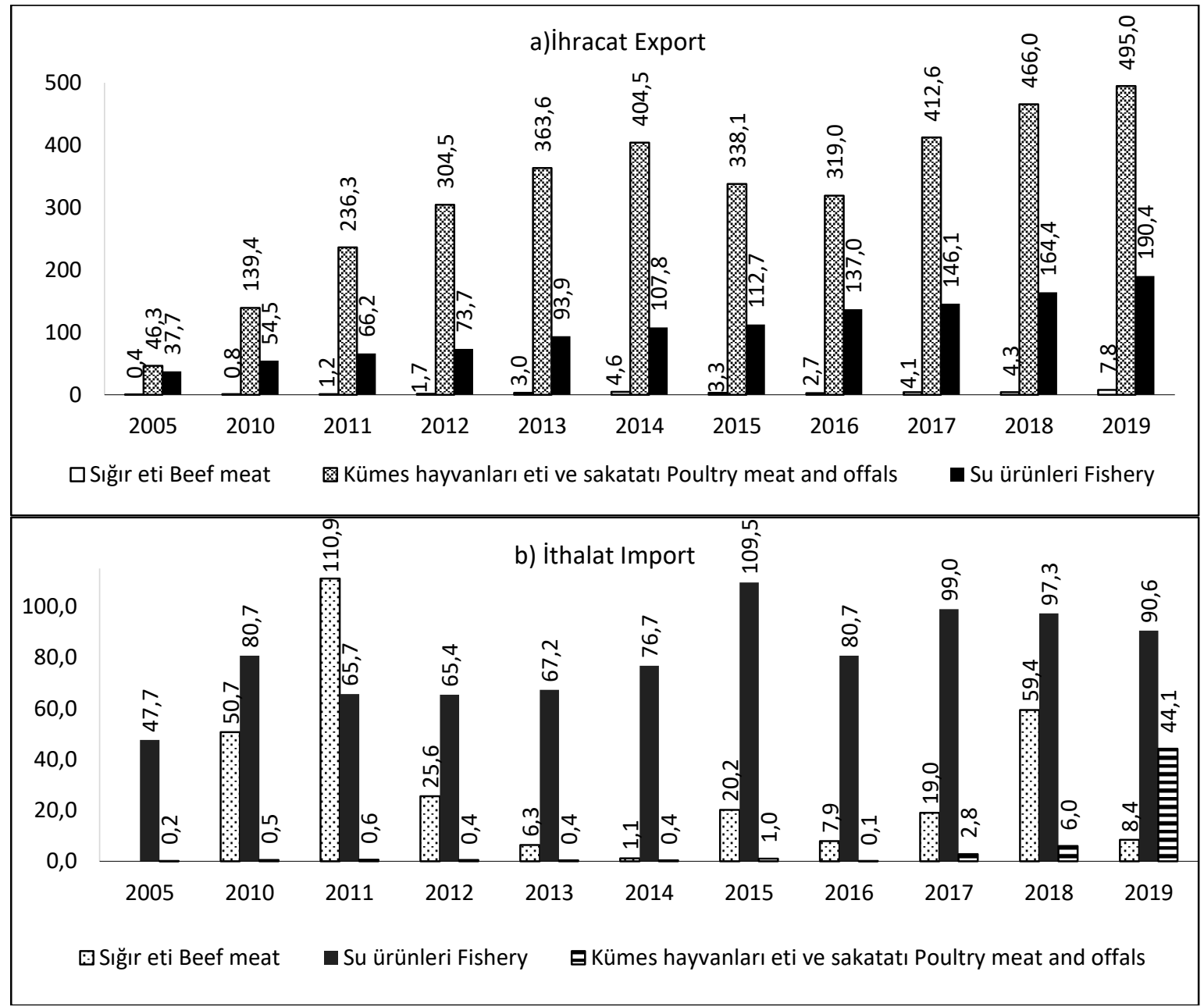

Şekil 2. Türkiye hayvansal ürünler dış ticaret miktarı (Bin ton)

Figure 2. Foreign trade of livestock products in Turkey (quantity: Thousand tons)

Kaynak Source: ITC (2020). 


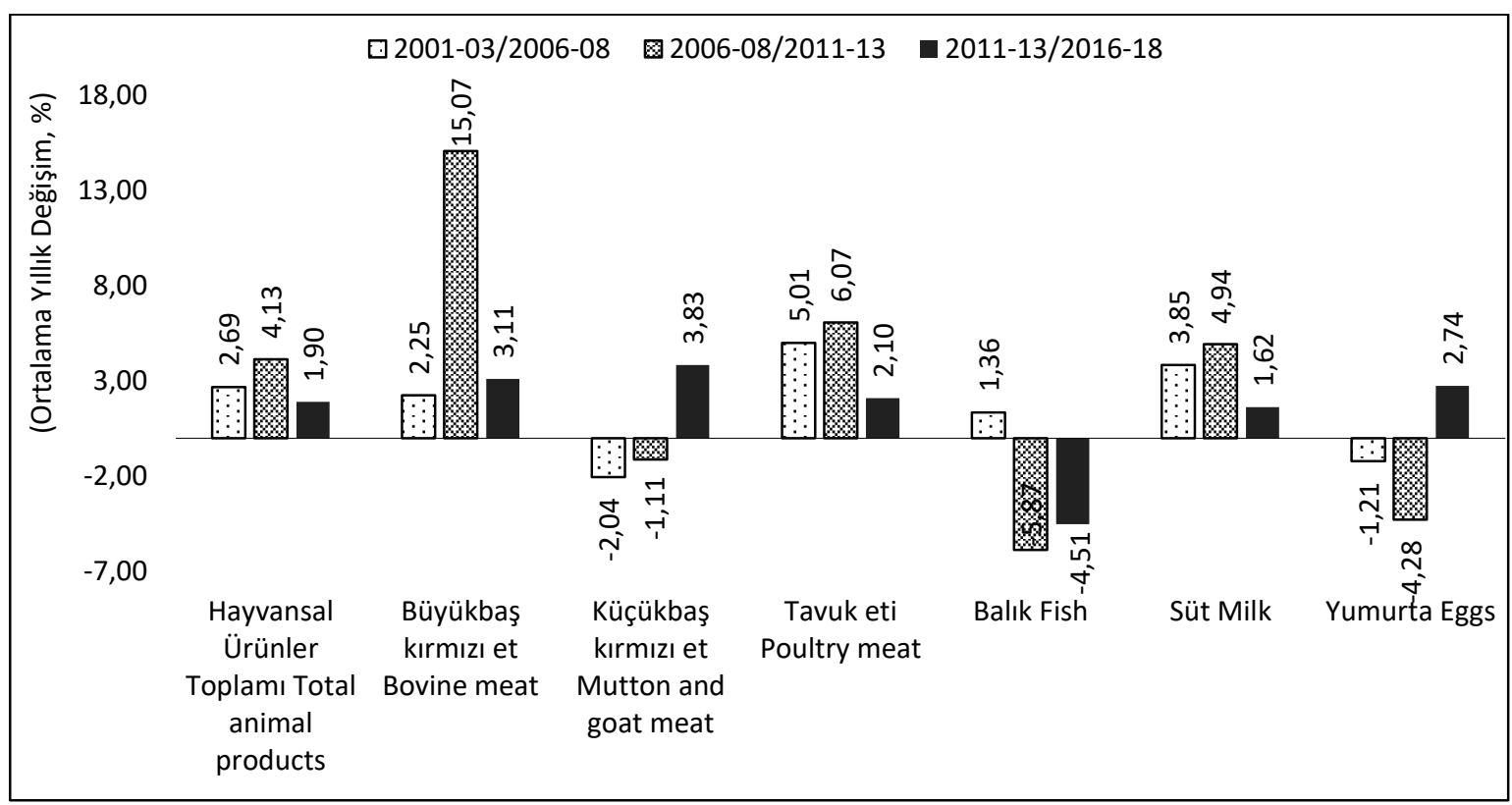

Şekil 3.Türkiye'de Kişi Başı Hayvansal Ürünler Arzındaki Gelişmeler (Ort.Yıllık Değişim \%) Figure 3. Development in Per Capita Animal Products Supply in Turkey (Average Annual Change \%)

Kaynak: FAO (2020b)'den hesaplanmıştır.

Source: Calculated from FAO (2020b)

Ürün bazında incelendiğinde ise, 2000’li yıllardan itibaren hayvancilık politikalarındaki köklü değişikliklerinde etkisiyle üretimdeki bir miktar artş̧la birlikte ithalattan kaynaklanan gida arzı artışının etkisi büyükbaş kırmızı et arzına yansımaktadır. Küçükbaş kırmızı et arzında ise 2011-2013 yılları arası döneme kadar yıllık kişi baş1 gıda arzında azalış görülmekte iken 2011 yılından itibaren özellikle hayvan sayısındaki artışa bağlı olarak yıllık kişi başı gıda arzında \%3.83 oranında artış yaşanmış̧ır. Tavuk eti gida arzında ise özellikle 2006-2008 ile 2011-2013 y1llar1 aras1 dönemde kişi başı yıllık ortalama \%6.07 oranında artış görülürken, 2011-2013 ile 2016-2018 y1llar1 arası dönemde bu artış hızı \%2.10'a gerilemiştir. Balık arzı ise incelenen beşer yıllık dönemlere göre istikrar göstermemekle birlikte 2011-2013 ile 2016-2018 yılları arası dönemde kişi başı yılllk ortalama gida arz1 \%4.51 oranında azalarak nüfus artışına karşı yeterli gıda artışının sağlanamadığı görülmektedir.

Süt arzında ise 2001 ile 2013 yllları arası dönemde kişi başı gıda arzı artış hızı \%3.85'den \%4.94'e ulaşırken, 2011-2013 yılları arası ile 2016-2018 yılları arası dönemde yıllık kişi başı süt gida arzı artış hızı yavaşlayarak \%1.62'ye düşmüştür. Diğer yandan, 2001-2003 y1llar1 arası ile 2011-2013 y1llar1 aras1 dönemde kişi baş1 yumurta arzı azalış göstermiştir. Bu dönemden itibaren ise bu düşüşs durdurularak ortalama yıllık \%2.74 oranında kişi başı gıda arzı artışı sağlanabilmiştir (Şekil 3).

\section{Türkiye'de Hayvanc1lık Politikaları}

Türkiye'de 2000'li yıllara kadar olan dönemde hayvancilık sektörüne yönelik sağlanan destekler bitkisel üretim ile kıyaslandığında oldukça sınırlı düzeylerde kalmıştır. Bu dönemde canlı hayvan ve hayvansal üretime yönelik uygulanan politikalar belirli dönemlerde ve kısa süreli olarak uygulanmıştır. Bu politika önlemleri arasında daha çok, damızlık hayvan dışalımı, karma yem satışında sübvansiyon ödemesi, sütte teşvik primi ödemesi, kırmız1 ve beyaz ette destekleme ödemeleri, özel sektöre yapay tohumlama faaliyetlerini desteklemek için teşvik pirimi ödemeleri ve hayvan sağlığında kullanılan ilaçlarda ilaç bedeli üzerinden belirli oranda yapılan iadeler bulunmaktadır (Gürer, 2013).

Türkiye'de 2000'li ylllardan itibaren ise içsel nedenler kadar dışsal nedenlerin de etkisiyle 
uygulamaya konulan "Tarım Reformu Uygulama Projesi" ile tarımsal üretimde girdi ve ürün destekleri büyük ölçüde kaldırılarak tarım politikalarında köklü değişikliklere gidilmiştir (Ören ve Bahadır, 2005). Bu dönemde "Hayvancilı̆̆ın Desteklenmesi ve Geliştirilmesi Projesi" başlatılmıştır. 2006 yllında çıkarılan Tarım Kanunu ile tarımsal desteklemelerin yasal çerçevesi oluşturulmuştur. Bu kanun ile kalkınma planı ve stratejileri doğrultusunda tarım sektörünün ve kırsal alanın geliştirilmesi ve desteklenmesi için gerekli politikaları belirlemek ve düzenlemeler yapmak amaçlanmıştır. $\mathrm{Bu}$ kapsamda, hayvancilığa yönelik destekleme araçlarının temel amaçları arasında hayvancılık faaliyetlerinde $1 \mathrm{rk}$ 1slahı, kaba yem üretiminin artırılmas1, verimliliğin artırilması, işletmelerin ihtisaslaşması, işletmelerde hijyen şartlarının sağlanması, hayvan sağlığı ve refahı, hayvan kimlik sisteminin teşviki, hayvansal ürünlerin işlenmesi ve pazarlanması ile bunlarla ilgili kontrol, takip ve standartların iyileștirilmesi ve su ürünlerinin desteklenmesi gelmektedir (Anonim, 2006).

Bu amaçlarla son yıllarda Türkiye'de hayvansal destekleme modeli içerisinde yem bitkileri, buzağ1-malak desteği, süt primi, çiğ sütün değerlendirilmesi, besili erkek sığır, koyun ve keçi desteği, çoban (sürü yöneticisi) istihdam desteği, hayvan gen kaynaklarının korunması, su ürünleri, arıcilı, tiftik, ipekböceği, hastalıktan ari işletmeler, hayvan hastalıkları tazminatları, aşı ve atık desteği gibi önemli destekleme araçları dikkati çekmektedir. Ayrıca bu desteklemelere ek olarak, tarımsal ürün ve hayvan hayat sigortaları, organik tarım ve hayvancilik destekleri, iyi tarım uygulamalanı, tarımsal yayım ve danışmanlık gibi destekler de destekleme modeli içerisinde giderek ağırlığını artırmaktadır.

Özetle 2000'li ylların ortalarından itibaren Türkiye'de hayvancılık politikalarında önemli değişimler gerçekleşmiştir. $\mathrm{Bu}$ dönemde destekleme kalem ve miktarlarnnda yapılan yeni düzenlemelerle hayvancilik desteklemelerinde yeni uygulamalar gündeme gelmiş ve toplam tarımsal destekler içerisinde hayvancilık desteklerinin payı artmıştır (Demir ve Yavuz, 2010). 1990 yllinda toplam destekler içerisinde hayvancillğın pay1 $\% 0.02$ iken, 2000 yilında $\% 0.5$, 2005 yilinda $\% 9.6,2010$ yilinda $\% 20.3$ ve 2020 yllında ise \%35.79'a ulaşmıstır (TOB, 2021).

\section{Türkiye'de Nüfusun Beslenme Yapısı ve Hayvansal Ürün Tüketimi}

Minimum besin enerji gereksinim miktar1, iyi beslenemeyen nüfusun belirlenmesinde eşik değer görevi görmektedir. Bir ülkedeki minimum besin enerji gereksinimi değeri, o ülkedeki farklı yaş ve cinsiyetteki bireylerin minimum enerji gereksinimlerinin ağıllıklı ortalamaları alınarak hesaplanmakta olup kişi başı kalori (kcal) cinsinden ifade edilmektedir (FAO, 2020b).

FAO (2020b) verilerine göre Türkiye'de minimum besin enerji gereksinimi artış eğiliminde olup 2017-2019 yılları ortalamasına göre kişi baş1 günlük 1828 kcal'dir. Benzer şekilde bireylerin ortalama besin gereksinimi ise kişi başı günlük $2372 \mathrm{kcal}$ olup bu değer dünya $(2369 \mathrm{kcal})$ ortalamasina yakın olup yüksek gelirli ülkeler ortalamasinın (2511 kcal) altındadır.

Türkiye'de 2016-2018 y1llar1 aras1 dönemde günlük g1da tüketimi kişi baş1 3713 kcal olup, bu değerin sadece \%15.6's1 (579 kcal) hayvansal kaynaklı gıdalar oluşturmakta geri kalanını ise bitkisel kaynaklı gıdalar oluşturmaktadır (FAO, 2020b). Ancak, 1995-2018 y1lları aras1 dönemde bireylerin günlük gida tüketim değeri hemen hemen aynı düzeyde gerçekleşirken hayvansal kaynaklı gidaların pay1 \%11.55'den \%16.30'a yükselmiştir. Hayvansal gıda gruplarına göre bireylerin kalori cinsinden hesaplanan günlük gıda tüketimleri incelendiğinde, 1995-2018 y1lları aras1 dönemde balık tüketiminin $\% 57.14$ oranında azaldığı, bununla birlikte aynı dönemde et ve et ürünleri tüketiminin \%67.39, hayvansal yağlar tüketiminin $\% 52.27$, süt ve süt ürünleri tüketiminin ise $\% 44.02$ oranında arttığ1 görülmektedir (Şekil 4).

FAO (2020b) verilerine göre, Türkiye'de kişi başı günlük protein alım miktarı bakımından son 30 yılda önemli bir değişim görülmemiş ve 20162018 y 1 llar1 aras1 ortalama 110 gr olarak gerçekleşmiştir. Bu değer dünya ortalamasının (82.73 gr) üzerinde ve gelişmiş ülkelerin 
ortalaması ile aynı düzeydedir. Ancak gelişmiş ülkelerden farklı olarak Türkiye'de tüketilen proteinin büyük bir oranı (\%65.29) bitkisel kaynaklıdır. Oysaki gelişmiş ülkelerde kişi başı günlük tüketilen proteinin yarıdan fazlasını hayvansal kaynaklı protein oluşturmaktadır.
Örneğin aynı dönemde $A B$ 'de toplam tüketilen proteinin \%58.30'unu, ABD'de ise \%64.6'sinı hayvansal kaynaklı proteinler oluşturmaktadır (FAO, 2020b).

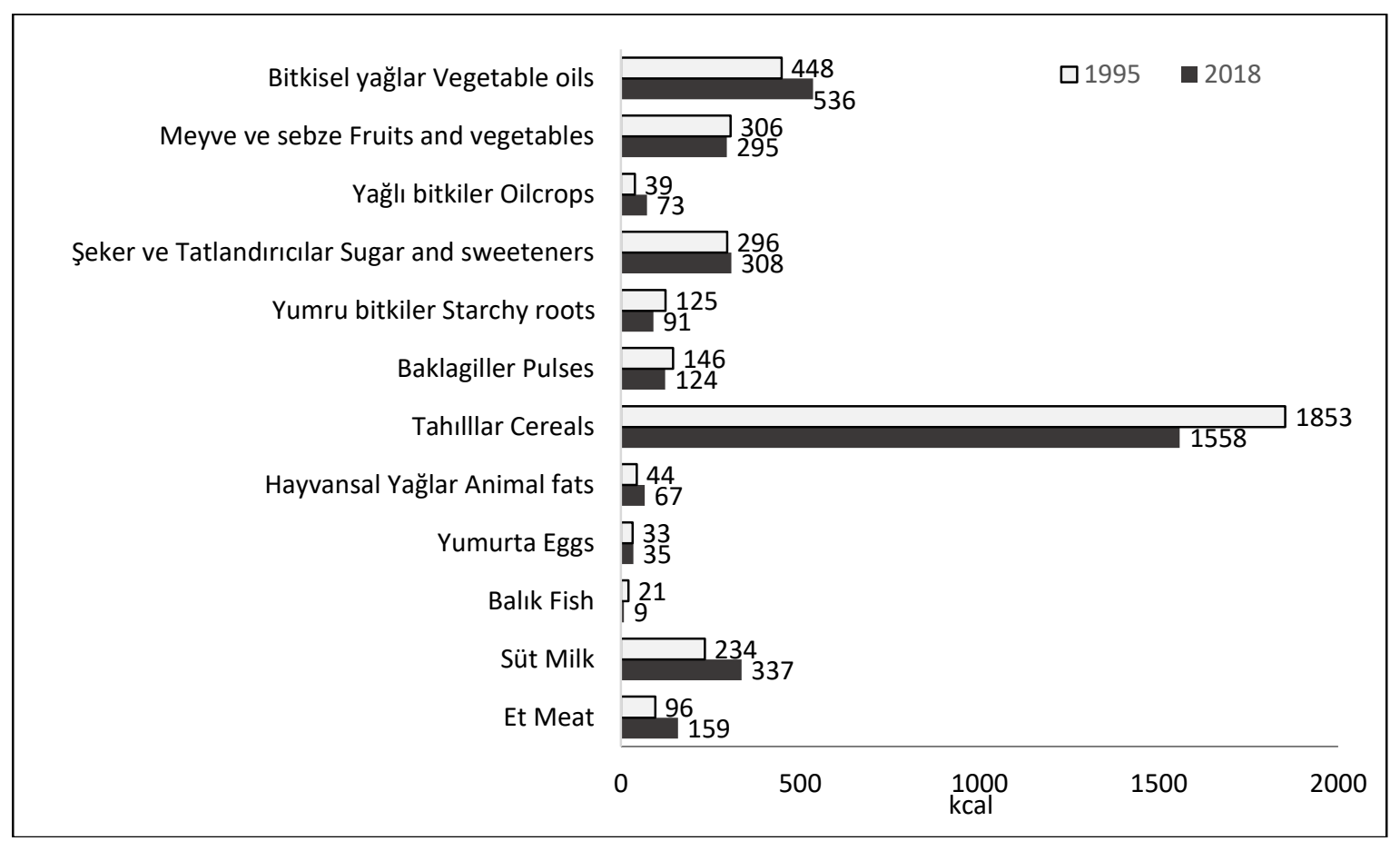

Şekil 4. Türkiye'de bireylerin kişi başı günlük g1da tüketim düzeyleri (kcal)

Figure 4. Per capita daily food consumption levels of individuals in Turkey (kcal)

Kaynak Source: FAO (2020).

Bununla birlikte Türkiye'de tüketilen hayvansal protein miktarı gelişimi incelendiğinde, 1995-97 y1lları ortalamasına göre günlük kişi başı hayvansal protein tüketimi 27.45 gr'dan 2018 yllında 39.5 gr'a yükselmiştir. Hayvansal protein tüketiminin artmasindaki en büyük pay ise et ve süt ürünleri tüketimindeki artıstan kaynaklanmaktadır. Türkiye'de tüketilen hayvansal proteinin yariya yakınını (\%49.85) süt ve süt ürünleri oluşturmaktadır. Günlük protein alımında et ürünlerinin katkısı en fazla tavuk etinden (7.04 gr) kaynaklanmaktadır. İncelenen dönemde günlük protein alımında balığın katkısı \%10.02'den (2.75 gr) \%3.32‘ye (1.31 gr) düşmüştür (Şekil 5).

Ayrıca, Türkiye'de hayvansal gıdaların kişi başı tüketim miktarları incelendiğinde süt ve süt ürünleri tüketimi dışındaki et, yumurta ve deniz ürünleri tüketiminin dünya ortalamasının da altında olduğu görülmektedir (Şekil 6). FAO (2020b) verilerine göre 2018 yllında Türkiye'nin kişi başı yılllk toplam et tüketimi ise $38.97 \mathrm{~kg}$ olup, dünya kişi başı toplam et tüketimi değerinin (42.55 $\mathrm{kg}$ ) altında gerçekleşmiştir. Türkiye kişi başı yıllık ortalama et tüketiminin 14.31 kg'1nı (\%36.72'sini) dana eti, 1.88 kg'inı (\%4.82'sini) koyun ve keçi eti oluşturmakta olup, geri kalanını (\%58.46'sını) ise kırmızı et açığını kapatan tavuk eti oluşturmaktadır. Bu bakımından incelendiğinde gelişmiş ülkelere göre Türkiye'de tüketilen etin bileşimi açısından da farklılıklar bulunmaktadır. Örneğin toplam et tüketimi içerisinde tavuk etinin pay1 ABD'de \%45.99 ve AB'de ise \%28.74'tür (FAO, 2020). Benzer şekilde 2018 yllında süt ve 


\section{B. Gürer}

süt ürünleri tüketimi bakımından Türkiye kişi baş1 $165.37 \mathrm{~kg}$ ile dünya ortalamasi $(78.01 \mathrm{~kg})$ ve gelişmekte olan ülkeler ortalamasının (135.29 kg) üzerinde, ancak gelişmiş ülkeler ortalamasının $(188.68 \mathrm{~kg})$ altındadır. Türkiye'de süt ve süt ürünleri tüketim alışkanlığ1 yaygın değildir. Türkiye'de kişi başı yumurta tüketimi $8.63 \mathrm{~kg}$ olup, bu değer dünya ortalamasının (9.59 kg/kişi) altındadır. Hayvansal ürün tüketimi bakımından bir diğer önemli husus ise Türkiye su ürünleri tüketiminde kişi baş1 $4.89 \mathrm{~kg}$ ile az gelişmiş ülkelerin ortalamasının (13.59 kg/kişi) da altında yer almaktadır. Dünyada su ürünleri tüketimi ise kişi baş1 $20.25 \mathrm{~kg}$ olup, gelişmiş ülkeler ortalaması $26 \mathrm{~kg}$ ve gelişmekte olan ülkeler ortalaması ise 13.86 kg'dır (Şekil 6).

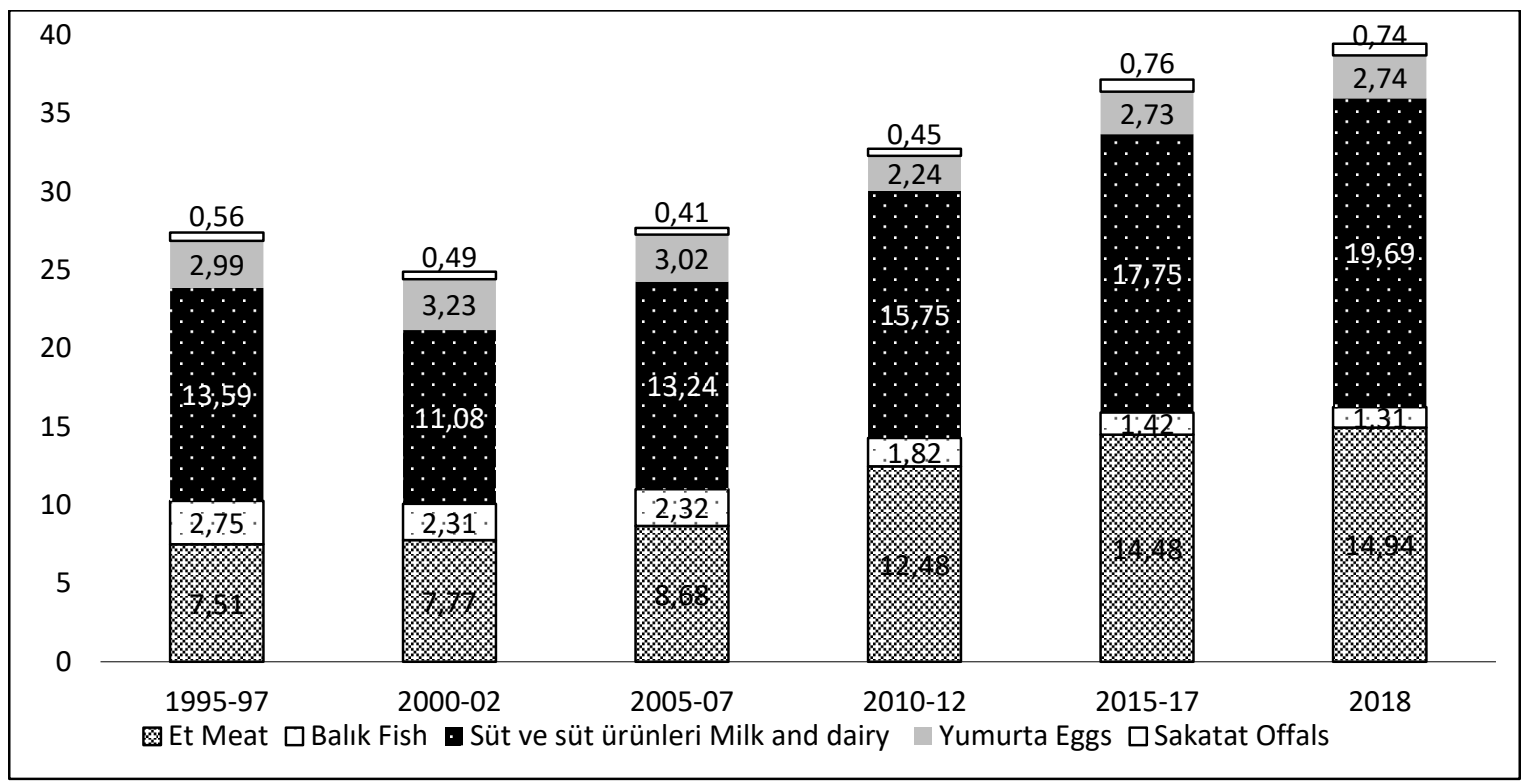

Şekil 5. Türkiye'de hayvansal protein alımında besin gruplarının dağllımı (gr/kişi/gün)

Figure 5. Distribution of food groups in animal protein intake in Turkey (gr/person/day)

Kaynak Source: FAO (2020b).

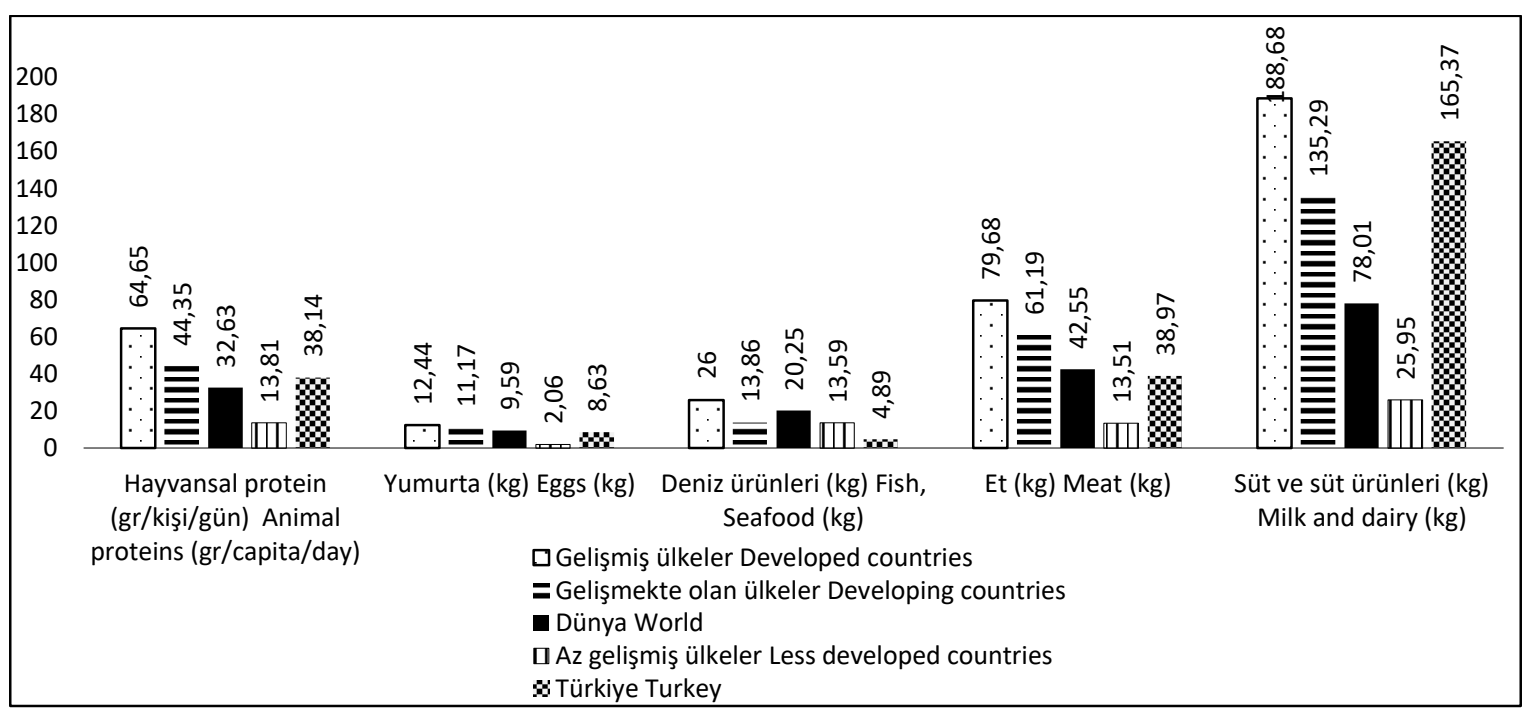

Şekil 6. Hayvansal ürün tüketimine göre ülkelerin karşılaştırılması (2018 y1lı)

Figure 6.Comparison of countries according to animal product consumption (2018)

Kaynak Source: FAO (2020b). 
Türkiye'de hayvansal ürün talebini etkileyen en önemli unsur ise fiyatlar ve gelirdir. Bu bakımından incelendiğinde 2005 yllından itibaren gıda fiyatlarındaki artış tüketici fiyatları enflasyonun üzerinde seyretmektedir (TÜIKK, 2021). Ayrica 2005-2019 y1lar1 aras1 dönemde g1da fiyatları endeksi 3.73 kat artarken, kişi baş1 reel gelir 1.66 kat artmıştır (TÜIKK, 2021). Bununla birlikte, 2005-2020 yıllar1 aras1 dönemde reel fiyatlarla dana eti fiyatlar1 \%12.9, koyun eti
$\% 42.74$, balık $\% 7.29$, yumurta $\% 15.38$ oraninda artarken, süt $\% 17.42$ ve tavuk eti fiyatlar1 ise \%1.60 oranında reel olarak azalmıştır (Şekil 7). Hayvansal ürün fiyatlarının artmasının başlıca nedenleri arasında, özellikle önemli girdi kalemlerini oluşturan yem ve damızlık materyali gibi girdilerin dışa bağlı olması nedeniyle üretim maliyetlerinin yüksekliği, hayvansal ürünlerde verim düşüklüğü ve etkin bir pazarlama zincirinin olmamasi gelmektedir (Gürer, 2020).

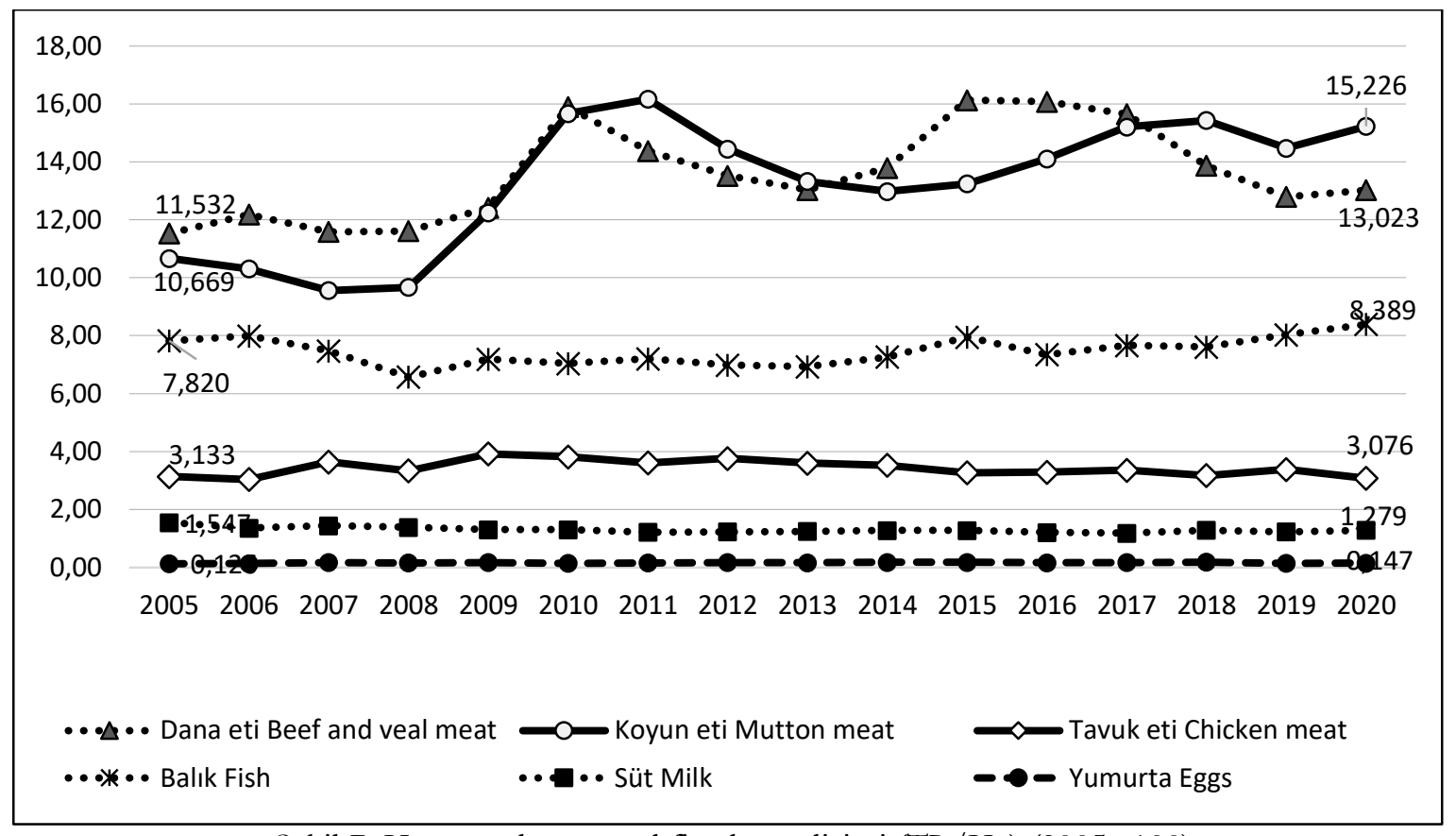

Şekil 7. Hayvansal ürün reel fiyatları gelişimi (TL/Kg) $(2005=100)$

Figure 7. The developments in animal products real prices (TL/g) $(2005=100)$

Kaynak Source: TÜİK (2021).

Diğer yandan hanelerin toplam gida harcamalarının gelir gruplarına göre dağılımları incelendiğinde, en düşük gelir grubunda yer alan hanelerin gıda harcamaları içerisinde daha çok ekmek ve tahıl (\%19.7), sebze (\%18.9), şekerli gidalar $(\% 9.4)$ ve yağ $(\% 4.9)$ gibi ürünlere daha fazla pay ayırırken, et, balık, meyve ve alkolsüz içecekler tüketiminin toplam gida harcaması içerisindeki payının azaldığı görülmektedir. Hayvansal ürün tüketimi bakımından, gelir artış1 ile birlikte toplam gida harcaması içerisinde et ve balık tüketim harcamalarının payı artarken, süt, peynir ve yumurta harcamalarının payı oransal olarak azalmaktadır (Şekil 8).
Türkiye'de hayvansal ürünlerin talebini etkileyen fiyat ve gelir gibi ekonomik unsurların dışında tüketicilerin sağlıklı beslenme, çevre bilinci, gıda güvenilirliği gibi unsurların da etkili olduğu söylenebilir. Son yillarda hayvansal ürünlerde görülen deli dana hastalı̆̆ı, kuş gribi ve diğer zoonoz hastalıklar ile birlikte bu ürünlerde tağşiş, hijyen ve kalite kontrolüne yönelik tüketicilerin sağlık kaygısı, günümüzde hayvansal gida talebinin en önemli belirleyicilerinden biri haline gelmektedir (Mutlu, 2007; Yllmaz ve Yilmaz, 2012; Saygın ve Demirbaş, 2018). Ayrica son y1llarda tüketici tercihleri arasında, geleneksel beslenme alışkanlıklarının, çevre ve sağlık kaygıları 
nedeniyle bitkisel kaynaklı protein kaynaklarını temel alan beslenme modelleri (Akdeniz tipi, vejetaryen ve vegan beslenme modelleri gibi) ile değiştirilmesi de söz konusudur (Can ve ark., 2021).

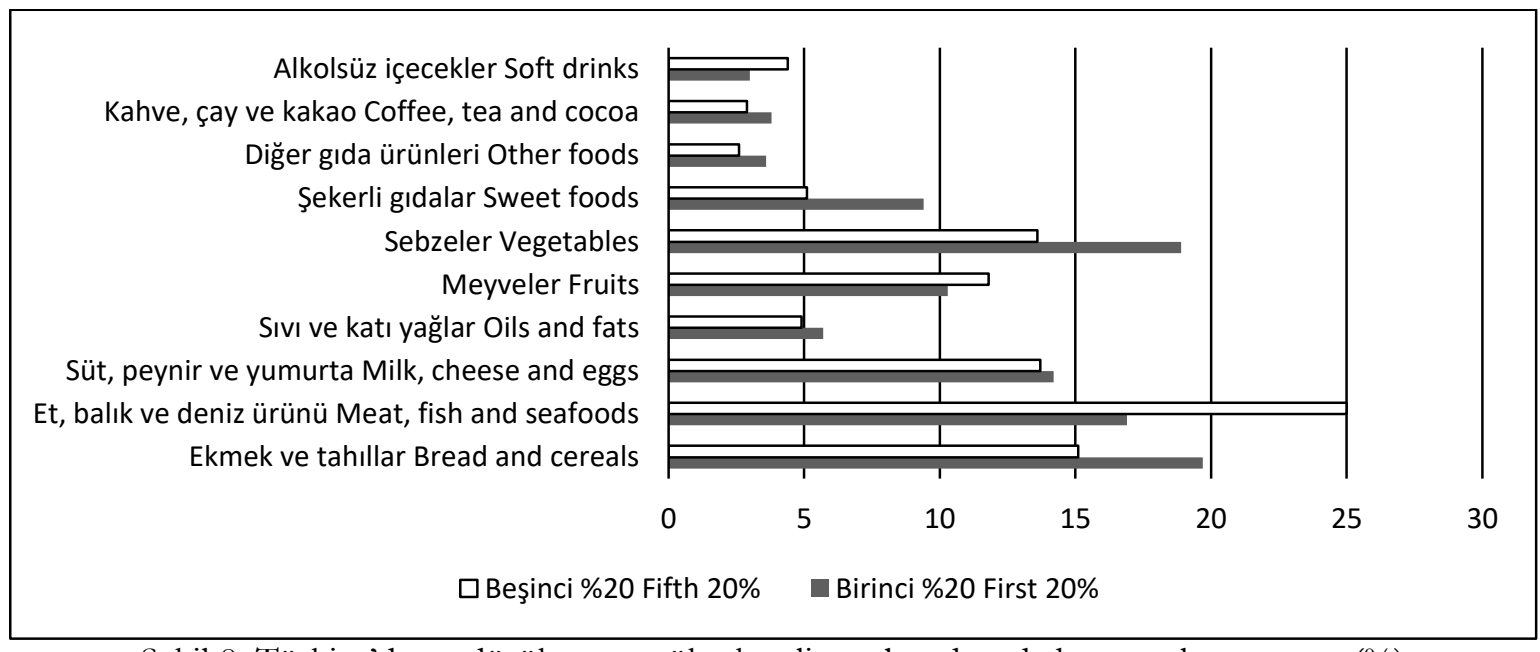

Şekil 8. Türkiye'de en düşük ve en yüksek gelir grubunda gıda harcamalarının payı (\%)

Figure 8. Share of food expenditures in the lowest and the bighest income groups in Turkey (\%)

Kaynak Source: TÜİK (2020c)

Nüfusun Yeterli ve Dengeli Beslenmesi İçin Hayvansal Ürün Arzı İhtiyacı

Çizelge 2., 3. Ve 4.'de Sağlık Bakanlığ1 (2019) tarafindan hazırlanan Türkiye Beslenme Rehberi (2015)'ne dayanarak her bir yaş grubunda cinsiyet faktörü de göz önüne alınarak uzmanlar tarafindan önerilen günlük hayvansal ürün tüketim miktarları hesaplanmıştır. Daha sonra bu referans değerler dikkate alınarak 2019 ve 2025 yılı yaş ve cinsiyete göre nüfus tahminleri kullanılarak toplam nüfusun yıllık hayvansal gida alım gereksinimleri hesaplanmıstır. $\mathrm{Bu}$ gereksinim içerisinde bireylerin haftada iki defa balık diğer bir ifade ile 11 yaş ve üstü bireyler için haftada 550 gram (1 porsiyon 275 gr) balık tükettikleri varsayılmıştır.

Buna göre uzmanların yaş ve cinsiyete göre önerdiği günlük beslenme kompozisyonu dikkate alındığında Türkiye'de nüfusun sağlıklı ve dengeli beslenebilmesi için 2019 yllı için hayvansal gida arzı ihtiyacı kırmızı et ve tavuk eti için 2 milyon 610 bin ton, balık için 2 milyon 263 bin ton, yumurta gida arzı ihtiyac1 1 milyon 126 bin ton ve süt ve süt ürünleri gıda arzı ihtiyacı ise 21 milyon 037 bin ton olarak hesaplanmıştır (Çizelge 2). Diğer bir ifade ile toplumun yeterli ve dengeli beslenebilmesi için kişi başı yıllık 31.39 kg kırmızı et ve tavuk, $27.22 \mathrm{~kg}$ balık, $13.54 \mathrm{~kg}$ yumurta ve $252.99 \mathrm{~kg}$ süt ve süt ürünleri arzına ihtiyaç bulunmaktadir.

Bu açıdan 2019 yılında bu gidalarda gerçekleşen arz miktarı incelendiğinde kırmızı et ve tavuk eti için 2 milyon 759 bin ton, balık için 737 bin ton, yumurta için 724 bin ton ve süt ve süt ürünlerinde ise 22 milyon 477 bin ton olarak gerçekleşmiştir (Şekil 9).

Gelişmekte olan ve az gelişmiş birçok ülke için alternatif ve ucuz protein kaynağ1 olarak ise balık tüketimi görülmektedir. $\mathrm{Bu}$ nedenle, beslenme sorunlarının çözümünde deniz ve iç sular kaynaklarından özellikle balıktan daha fazla oranda yararlanmak dünya beslenme politikasının temel ve önde gelen unsurlarından biri haline gelmiştir. Ancak Türkiye'de bireylerin balık tüketim miktarı dünya ortalamasının da oldukça altındadır. Şen ve Şahin (2017) tarafindan Mersin ilinde yürüttüğü çalışmada tüketicilerin \%43'ünün haftada bir defa balık eti, \%42'si ise ayda bir defa balık eti tükettiğini belirlemiștir. Terin ve ark. (2016) Van ili kentsel alanda yaptıkları araştırmada hanelerin \%30.6's1 on beş günde bir balık 
tüketirken, \%30.2'si haftada bir ve \%25.4'ü ise ayda bir balık tükettiklerini bulmuşlardır. Bu bulgular göz önüne alınarak Türkiye'de bireylerin et, tavuk ve balık arzı gereksinimi 2019 yılı nüfus verilerine göre Çizelge 3'de tekrardan değerlendirilmiştir. Buna göre Türkiye'de bireylerin haftada bir balık tüketmesi durumunda toplam et ve tavuk arzi ihtiyac1 3 milyon 21 bin tona yükselirken, balık arzı ihtiyacı ise 1 milyon 132 bin ton olarak hesaplanmıştır. Bununla birlikte bireylerin on beş günde bir balık tüketmesi halinde kırmızı et ve tavuk eti arzı ihtiyacinın 3 milyon 241 bin tona yükseldiği ve balık arzı ihtiyacının ise 566 bin ton olduğu hesaplanmıştır. Diğer bir senaryo ise Türkiye'de bireylerin ayda bir defa balık tüketmesi durumunda ise kırmızı et ve tavuk eti ihtiyacinın 3 milyon 337 bin tona yükselirken balık arzı ihtiyacının ise 283 bin tona düştüğü görülmüştür.

Çizelge 2. Türkiye'de 2019 yılı nüfusunun besin gereksinimine uygun hayvansal ürün gida arz1 ihtiyac1 (1000 ton/yl)

Table 2. Animal product food supply requirement in accordance with the nutritional needs of the population of 2019 in Turkey (1000 tons / year)

\begin{tabular}{|c|c|c|c|c|c|}
\hline \multicolumn{2}{|c|}{ Ürünler Products } & $\begin{array}{l}\text { Kırmızi et } \\
\text { ve tavuk eti } \\
\text { Red meat and } \\
\text { chicken meat }\end{array}$ & $\begin{array}{l}\text { Balik } \\
\text { Fish* }\end{array}$ & $\begin{array}{l}\text { Yumurta } \\
\text { Eggs }\end{array}$ & $\begin{array}{c}\text { Süt ve süt } \\
\text { ürünleri } \\
\text { Milk and } \\
\text { dairy } \\
\text { products** }\end{array}$ \\
\hline \multirow{7}{*}{$\begin{array}{l}\text { Yaş gruplar1 } \\
\text { Age groups }\end{array}$} & $0-4$ & 52.39 & 60.66 & 99.26 & 1111.67 \\
\hline & $5-9$ & 202.14 & 185.29 & 84.22 & 1560.24 \\
\hline & $10-14$ & 200.42 & 183.72 & 83.51 & 1683.54 \\
\hline & $15-19$ & 249.00 & 181.58 & 91.02 & 1663.94 \\
\hline & $20-49$ & 1275.10 & 1073.73 & 505.35 & 9839.28 \\
\hline & $50-69$ & 480.01 & 440.01 & 200.00 & 4032.09 \\
\hline & $\begin{array}{l}70 \text { ve yukaris1 } \\
70 \text { and above }\end{array}$ & 151.05 & 138.46 & 62.94 & 1146.52 \\
\hline \multicolumn{2}{|c|}{$\begin{array}{l}\text { Toplam nüfusun ylllik gereksinimi } \\
\text { Required amount of the total population }\end{array}$} & 2610.11 & 2263.45 & 1126.31 & 21037.28 \\
\hline \multicolumn{2}{|c|}{$\begin{array}{l}\text { Kişi baş1 gereksinim miktar1 (kg/yıl) } \\
\text { Required amount per capita (kg/year) }\end{array}$} & 31.39 & 27.22 & 13.54 & 252.99 \\
\hline \multicolumn{2}{|c|}{$\begin{array}{l}\text { Gerçekleşen toplam arz miktarı } \\
\text { Total actual supply amount }\end{array}$} & 2759.39 & 736.77 & 724.42 & 22476.68 \\
\hline \multicolumn{2}{|c|}{$\begin{array}{l}\text { Kişi baş1 gerçekleşen arz miktarl (kg/yll) } \\
\text { Actual supply amount per capita (kg/year) }\end{array}$} & 33.18 & 8.86 & 8.71 & 270.30 \\
\hline
\end{tabular}

Kaynak: TÜíK (2020a), TÜíK (2020b) ve Sağlık Bakanlığı (2019)'dan faydalanılarak hesaplanmıştır.

Source: Calculated from TÜIK (2020a), TÜIK (2020b) and the Ministry of Health (2019).

* Uzmanların önerdiği haftada iki defa balık tüketilmesi halinde ele alınan senaryo

* Scenario addressed if fish is consumed twice a week recommended by experts

** süt eşdeğerini ifade eder.

** refers to the milk equivalent.

Ayrıca, 2025 y1lı yaş ve cinsiyete göre nüfus tahmini baz alınarak hayvansal ürünlerde arz ihtiyacına yönelik öngörüde bulunulmuştur (Çizelge 4). Buna göre 2025 y1l için toplam nüfusun yeterli ve dengeli beslenebilmesi için kırmızı et ve tavuk eti arzı ihtiyacinın 2 milyon 782 bin ton, balık ihtiyacinın 2 milyon 421 bin ton, yumurta arzi ihtiyacinin 1 milyon 201 bin ton ve süt ve süt ürünleri arzı ihtiyacının ise 22 milyon 470 bin ton olacağ1 öngörülmüştür. 


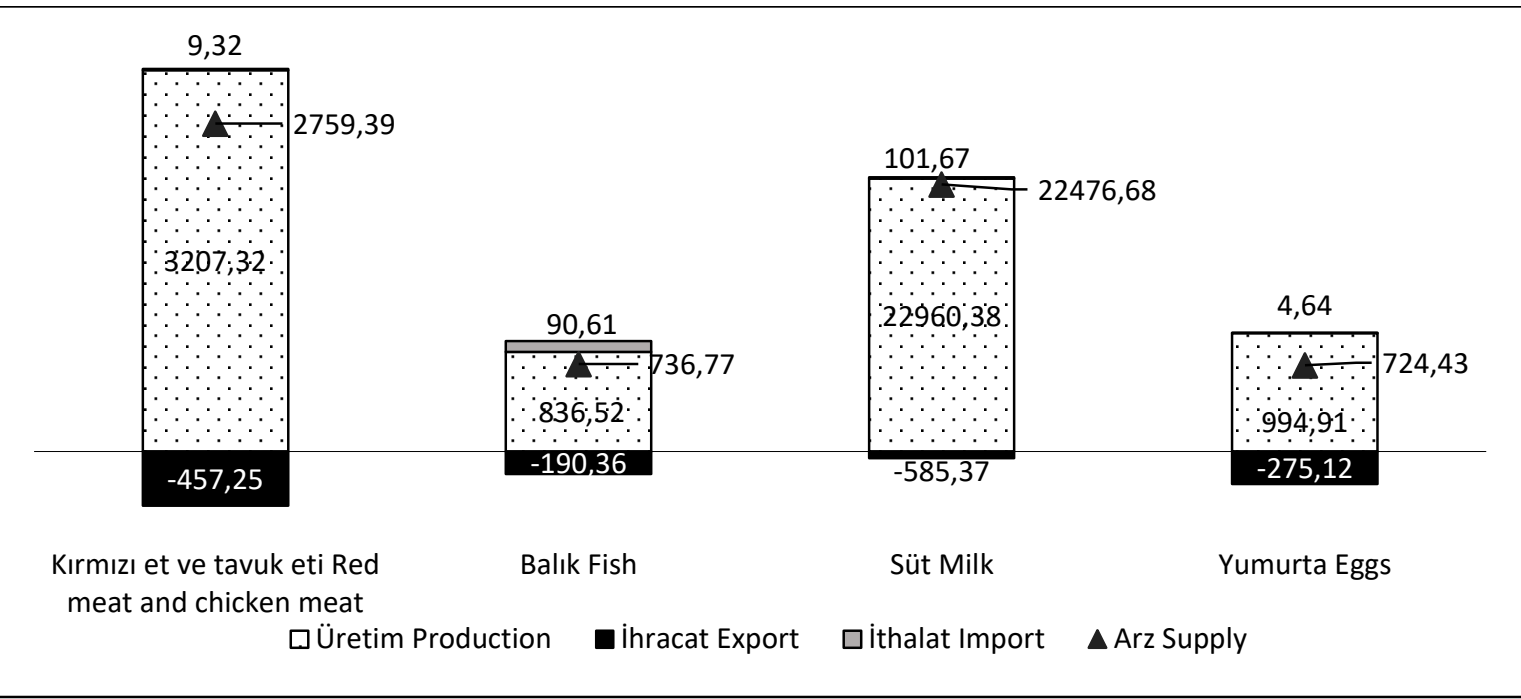

Şekil 9. 2019 yllı hayvansal ürünler gerçekleşen arz miktarı (Bin ton)

Figure 9. Total actual supply for animal products in 2019

Kaynak Source: ITC (2020); TÜIK (2020b)

Çizelge 3. Türkiye'de 2019 yll nüfusunun besin gereksinimlerine uygun et ve balık arzı ihtiyac1 Table 3. Required meat and fish amount in accordance with the nutritional needs of the population of 2019 in Turkey (1000 tons / year)

\begin{tabular}{|c|c|c|c|c|c|c|c|c|c|c|}
\hline & \multicolumn{7}{|c|}{ Yaş gruplar1 Age groups } & \multirow{2}{*}{$\begin{array}{l}\mathrm{TYG}^{1} \\
A \mathrm{R} A^{1}\end{array}$} & \multirow{2}{*}{$\begin{array}{l}\mathrm{KBG}^{2} \\
\mathrm{RAPC}\end{array}$} & \multirow{2}{*}{$\begin{array}{l}\mathrm{KBB}^{3} \\
A P C^{3}\end{array}$} \\
\hline & $0-4$ & $5-9$ & $10-14$ & 15-19 & $20-49$ & $50-69$ & $70+$ & & & \\
\hline \multicolumn{11}{|c|}{ Haftada bir defa balık tüketildiğinde In case of fish consumption once a week } \\
\hline $\begin{array}{l}\text { Et, tavuk } \\
\text { Meat and } \\
\text { chicken }\end{array}$ & 63.41 & 235.83 & 233.83 & 282.02 & 1470.33 & 560.01 & 176.22 & 3021.65 & 36.34 & -3.16 \\
\hline $\begin{array}{l}\text { Balik } \\
\text { Fish }\end{array}$ & 30.33 & 92.65 & 91.86 & 90.79 & 536.87 & 220.00 & 69.23 & 1131.73 & 13.61 & -4.75 \\
\hline \multicolumn{11}{|c|}{ Balık 15 günde bir defa tüketildiğinde In case of fish consumption once in 15 days } \\
\hline $\begin{array}{l}\text { Et, tavuk } \\
\text { Meat and } \\
\text { chicken }\end{array}$ & 69.30 & 253.80 & 251.64 & 299.63 & 1574.45 & 602.68 & 189.65 & 3241.14 & 38.98 & -5.8 \\
\hline $\begin{array}{l}\text { Balik } \\
\text { Fish }\end{array}$ & 15.16 & 46.32 & 45.93 & 45.40 & 268.43 & 110.00 & 34.62 & 565.86 & 6.80 & 2.06 \\
\hline \multicolumn{11}{|c|}{ Balık ayda bir defa tüketildiğinde In case of fish consumption once a month } \\
\hline $\begin{array}{l}\text { Et, tavuk } \\
\text { Meat and } \\
\text { chicken }\end{array}$ & 71.87 & 261.66 & 259.43 & 307.33 & 1620.00 & 621.35 & 195.52 & 3337.16 & 40.13 & -6.95 \\
\hline $\begin{array}{l}\text { Balik } \\
\text { Fish }\end{array}$ & 7.58 & 23.16 & 22.96 & 22.70 & 134.22 & 55.00 & 17.31 & 282.93 & 3.40 & 5.46 \\
\hline
\end{tabular}

${ }_{1}^{1}$ TYG: Toplam Yillık Gereksinim, ARA: Annual required amonut

${ }^{2}$ KBG: Kişi Başı Gereksinim (kg/yıl), RAPC: Required amount per capita (kg/year)

${ }^{3}$ KBB: Kişi Başı Bulunabilirlik (kg/yıl), APC: Availability per capita (kg/year)

Kaynak: TÜİK (2020a), TÜİK (2020b) ve Sağlık Bakanlığ1 (2019)'dan faydalanılarak hesaplanmıştır.

Source: Calculated from TÜIK (2020a), TÜIK (2020b) and the Ministry of Health (2019). 
Çizelge 4. Türkiye'de 2025 y1lı nüfusunun besin gereksinimine uygun hayvansal ürünler g1da arzı ihtiyac1 (1000 ton/yl)

Table 4. Required animal products amount in accordance with the nutritional needs of the population of 2025 in Turkey (1000 tons / year)

\begin{tabular}{|c|c|c|c|c|c|}
\hline \multirow[t]{2}{*}{ Ürünler Products } & \multicolumn{2}{|c|}{$\begin{array}{l}\text { Kirmizi et ve tavuk eti } \\
\text { Red meat and chicken meat }\end{array}$} & \multirow{2}{*}{$\begin{array}{l}\text { Balik* } \\
\text { Fish } \\
63.22\end{array}$} & \multirow{2}{*}{$\begin{array}{c}\text { Yumurta } \\
\text { Hen eggs }\end{array}$} & \multirow{2}{*}{$\begin{array}{l}\text { Süt ve ürünleri } \\
\text { Milk and dairy } \\
1158.60\end{array}$} \\
\hline & $0-4$ & 54.60 & & & \\
\hline \multirow{6}{*}{$\begin{array}{l}\text { Yaş gruplar1 } \\
\text { Age groups }\end{array}$} & $5-9$ & 206.08 & 188.91 & 85.87 & 1590.55 \\
\hline & $10-14$ & 205.14 & 188.05 & 85.48 & 1723.18 \\
\hline & $15-19$ & 253.27 & 184.75 & 92.60 & 1692.96 \\
\hline & $20-49$ & 1304.99 & 1101.46 & 517.90 & 10093.36 \\
\hline & $50-69$ & 560.05 & 513.38 & 233.35 & 4704.38 \\
\hline & $\begin{array}{l}70 \text { ve yukaris1 } \\
70 \text { and above }\end{array}$ & 198.23 & 181.71 & 82.59 & 1506.98 \\
\hline \multicolumn{2}{|c|}{$\begin{array}{l}\text { Toplam nüfusun yllik gereksinimi } \\
\text { Required amount of the total population }\end{array}$} & 2.782 .35 & 2421.46 & 1201.23 & 22470.01 \\
\hline \multicolumn{2}{|c|}{$\begin{array}{l}\text { Kişi başı y1llik gereksinim } \\
\text { Required amount per capita (kg/year) }\end{array}$} & 33.46 & 29.12 & 14.45 & 270.22 \\
\hline
\end{tabular}

Kaynak: TÜİK (2020a), TÜİK (2020b) ve Sağlık Bakanlığı (2019)'dan faydalanılarak hesaplanmıştır.

Source: Calculated from TÜIK (2020a), TÜIK (2020b) and the Ministry of Health (2019).

* Uzmanların önerdiği haftada iki defa (1 porsiyon 250-300 gr) balık tüketilmesi halinde ele alınan senaryo

* Scenario addressed if fish is consumed twice a week recommended by experts

\section{SONUÇ}

Çalışma kapsamında, bireylerin yeterli ve dengeli beslenebilmesi için uzmanlar tarafindan yaş ve cinsiyete göre önerilen günlük besin alımı referans değerleri kullanılarak, Türkiye nüfusunun 2019 yllı ve 2025 yılı için hayvansal ürünler arz ihtiyacının ve yeterliliğinin değerlendirilmesi amaçlanmıştır. Bu kapsamda Türkiye'de hayvansal ürün arzının gelişimi, nüfusun beslenme yapisı ve hayvansal ürün tüketim durumları da incelenmiştir.

Çalışma sonucunda, Türkiye'de son yıllarda hayvancllı sektörüne yönelik uygulanan politikalardaki değişikliklerin, hayvan varllğına ve dolayısıyla üretime olumlu yönde yansıdı̆g1 görülmüştür. Ancak artan nüfus karşısında hayvansal ürünler üretimindeki bu artış, ne yazık ki toplumun yeterli ve dengeli beslenmesini temin edecek boyutta olmamışır. $\mathrm{Bu}$ durumun sonucunda Türkiye'de nüfus, ağırlıklı olarak tahıla dayalı ve yetersiz hayvansal ürün tüketen dengesiz bir beslenme yapısına sahip olmuştur. Bu açıdan değerlendirildiğinde Türkiye'de gizli açlı̆ın varlığından söz edilebilir.
Çalısma kapsamında, nüfusun mevcut beslenme kompozisyonu dikkate alındığında kırmızı et ve tavuk eti gereksiniminin gerçekleşen arz ile karşılanamadığ1 görülmüştür. Kırmızı ete alternatif olarak tüketilen tavuk eti arzında ise son yıllarda kişi başı ürün arzı artış hızı yavaşlamıştır. Diğer taraftan, hayvansal ürün üretimindeki girdilerin dışa bağlı olması nedeniyle üretim maliyetlerinin yüksek oluşu, hayvansal ürünlerde verim düşüklüğü ve örgütlenme ve pazarlama yapısından kaynaklı sorunlar nedeniyle oluşan ürün fiyatlarındaki artışlar, tüketicilerin satın alma gücündeki artışı üzerinde gerçekleşmektedir. Bu durum ise, tüketicilerin gida maddeleri satın alımında nispeten pahalı olan hayvansal ürünlere erişilebilirliğini güçleştirmektedir. Dolayısıyla, nüfusun gereksinimine uygun hayvansal ürünler arzının ve erişilebilirliğinin sağlanması sadece üretim boyutu ile değil, hayvansal ürünler arz zincirine yönelik bütüncül tedbirlerin birlikte alınması ile mümkün gözükmektedir. Aksi takdirde, gelecek yıllarda nüfusun bu ürünlere erişilebilirliğinin daha da hassas bir durumda olacağı muhtemeldir. 
Bununla birlikte Türkiye'de son yirmi yılda balık arzındaki özellikle kültür (yetiştiricilik) ile elde edilen balık üretimindeki önemli artışlara rağmen, kişi başı gerçekleşen arz miktarı nüfusun yeterli ve dengeli beslenebilmesini temin edecek miktarın oldukça altındadır. Buna ek olarak, son yirmi yılda balık etinin kişi başı günlük hayvansal protein alımına katkısı azalmaktadır. Dolayısıyla, Türkiye'nin sahip olduğu doğal kaynaklarına rağmen gerek denizlerde gerekse iç sularda su ürünleri kaynaklarını daha rasyonel kullanmaya ihtiyac1 vardır. Ayrıca, kültür balıkçılığının (yetiştiricilik) yaygınlaştırılmasına yönelik uygulanan teşvik ve desteklerin artırılarak devam ettirilmesi önemlidir. Balık üretimi ve tüketiminin artırılmasına yönelik teşvik ve destekler gelecek yıllarda gittikçe artan et arzı açığının kapatılmasına da katk1 sağlayacaktır.

Sonuç olarak, Türkiye hayvansal gida üretimi ve tüketiminde bütün kaynaklarını etkin bir şekilde kullanmak durumundadır. Bununla birlikte, hayvansal ürünler arzındaki temel sorunlar çözülemeden toplumun hayvansal ürün tüketiminde arzu edilen seviyeye ulaşılamayacağ da açıtır. Bu nedenle Türkiye'de hayvansal gıda üretimine katkıs1 olan bütün türlerin önemli olduğu gerçeği göz önüne alınarak politikalar uzun vadeli ve dayanakları sağlam öngörülere göre yapılmalıdır. Gıda, beslenme, sağlık birbirinden ayrılmaz kavramlar oldukları için sağlık ve tarım sektörlerinin bu konularda iş birliği içinde çalışmaları önemlidir. Tarım politikalarının belirlenmesinde toplumun beslenme sorunlar1 dikkate alınarak üretim planlanmalıdır. Ayrıca hayvansal ürünler tüketimine yönelik, toplumda yeterli ve dengeli beslenme alışkanlığ1 kazandıracak ülkesel boyutta teşvik ve destek kampanyalarının yaygınlaştırılması ve sürekliliğinin sağlanması önerilmektedir.

\section{ÇIKAR ÇATIŞMASI BEYANI}

Yazar, bu çalışmanın yapılması ve yayınlanması ile ilgili olarak herhangi bir çıkar çatışması olmadığını beyan etmektedir.

\section{KAYNAKLAR}

Alev, N. (2015). Kirmızı et talep tahmini: Van ili üzerine bir uygulama. Yüzüncü Yıl Üniversitesi,
Sosyal Bilimler Enstitüsü, İktisat Anabilim Dalı, İktisat Teorisi Bilim Dalı, Yüksek Lisans Tezi, Van, Türkiye, $125 \mathrm{~s}$.

Anonim (2006). Tarım Kanunu (Sayl: 5488). 25.04.2006 tarih ve say1 26148, Resmî Gazete, Başbakanlık, Ankara (Türkiye).

Aytop, Y., Iş1k, F. (2020). Gaziantep ilindeki tüketicilerin yumurta tüketim alışkanlıklarının belirlenmesi. Türk Tarm Doğa Bilim Derg, (7)1:269275, doi: 10.30910/turkjans. 680088

Can, B., Bayram, H.M., Öztürkcan, S.A. (2021). Çevresel sorunlara karşı çözüm önerileri: güncel sürdürülebilir beslenme uygulamalarına genel bakış. Gıda, 46(5):1138-1157, doi:10.15237/ gida.GD21062.

Can, B.A. (2019). Türkiye'de yumurta üretimi, tüketimi, ihracatı ve geleceği. International Marmara Sciences Congress, Kasim 2019, Kocaeli, Türkiye.

Demir, N., Yavuz, F. (2010). Hayvancillk destekleme politikalarına çiftçilerin yaklaşımlarının bölgelerarası karşılaştırmalı analizi. Atatürk Üniv J Fac Agric, 41(2):113-121. https://dergipark.org.tr/tr/download/articlefile/35357 (Erişim: 02.05.2021).

Doğan, N. (2019). TRA1 Bölgesinde (Erzurum, Erzincan, Bayburt) hanelerin kırmız1 et, tavuk eti ve balık eti tüketimine yönelik mevcut durum üzerine bir araştırma. Türk Tarm Doğa Bilim Derg, 6(2):285-295, doi: 10.30910/turkjans.557121.

FAO (2002). Food Security: Concepts and Measurement http://www.fao.org/3/y4671e/ y4671e06.htm\#bm06 (Erişim: 10.08.2021).

FAO (2020a). The State of Food Security and Nutrition in the World 2020. Transforming food systems for affordable healthy diets. Rome, FAO. Doi: https://doi.org/10.4060/ca9692en

FAO (2020b). Food Security Statistics. http://www.fao.org/faostat/en/\#data (Erişim: 20.10.2020).

Güngör, E.S., Ceyhun, S.B. (2017). Erzurum ve Van illerindeki balık tüketimi ve tüketici tercihleri üzerine bir araştırma. Alnteri J Agric Sci, 32(2): 110, doi: 10.28955/alinterizbd.298341. 
Gürer, B. (2013). Türkiye'de hayvansal ürünlerde g1da güvencesinin analizi. Çukurova Üniversitesi, Fen Bilimleri Enstitüsü, Tarım Ekonomisi ABD, Doktora Tezi, 206 s.

Gürer, B. (2020). Investigation of the lagged effects of livestock supports on the animal production value in Turkey Eurasian J Agric Res, 4 (2):144-156, https://dergipark.org.tr/tr/pub/ejar/ issue / 58112/822066 (Erişim:02.09.2021)

Hatırlı, S.A., Öztürk, E., Aktaş, A.R. (2007). Kırmızı, tavuk ve beyaz et talebinin tam talep sistemi yaklaşımıyla analizi. Süleyman Demirel Üniversitesi Sosyal Bilimler Enstitïsü Dergisi, (6):211221.

https://dergipark.org.tr/tr/pub/sbe/issue/2319 9/247805 (Erişim: 01.12.2020)

ITC (2020). International Trade Center (ITC) Trade-Map. www.trademap.net (Erişim: 01.11.2020)

Karakaya, E., Kızıloğlu, S. (2018). Bingöl İli Kent Merkezinde Tüketicilerin Süt ve Süt Ürünleri Tüketim Alışkanlıkları. KSÜ Tar Doğa Derg, 21(Özel Say1): 12-21, doi:10.18016/ ksutarimdoga.vi.504487.

Mutlu, S. (2007). Gıda güvenliği açısından tüketici davranışları (Adana kentsel kesimde kırmızı et tüketimi örneği). Çukurova Üniversitesi. Fen Bilimleri Enstitüsü Doktora Tezi, Tarım Ekonomisi Ana Bilim Dal,, Adana, 220s. http://traglor.cu.edu.tr/objects/objectFile/e7bS WTUE-492013-8.pdf (Erişim: 10.08.2021)

Ören, M.N., Bahadır, B. (2005). Türkiye'de ve OECD ülkelerinde hayvansal ürün politikaları ve bu politikalar sonucu ortaya çıan transferler. $J$ Anim Prod, 46(1):1-7. https://dergipark.org.tr/tr/ download/article-file/85125 (Erişim: 04.05.2021)

Öztornacı, B. (2013). Türkiye'de kırmızı et arzının analizi. Çukurova Üniversitesi Fen Bilimleri Enstitüsü, Tarım Ekonomisi Anabilim Dalı Yüksek Lisans Tezi, Adana, Türkiye, $91 \mathrm{~s}$.

Özyürek, S., Çebi, K., Türkyılmaz, D., Esenbuğa, N., Dağdelen, Ü., Yaprak, M. (2019). Erzincan ilinde kırmızı et tüketim alışkanlıkları ve tüketicilerin ithal kırmızı ete bakış açlarının değerlendirilmesi. Erz̨incan Univ J Sci Tech, 12(1):263-273, doi: 10.18185/erzifbed.449704.

Sağllk Bakanlı̆̆1 (2019), Türkiye Beslenme Rehberi 2015 (TÜBER), T.C. Sağlık Bakanlığ1 Halk Sağllğ1 Genel Müdürlüğü, Yayın No: 1031, Ankara. ISBN: 978-975-590-608-9

Sayg1, H., Bayhan, B., Hekimoğlu, M.A. (2014). Türkiye'nin İzmir ve Ankara illerinde su ürünleri tüketimi, Türk J Agric Food Sci Tech, 3(5):248-254.

Saygın, Ö., Demirbaş, N. (2017). Türkiye'de kırmızı et sektörünün mevcut durumu ve çözüm önerileri. Hayvansal Üretim, 58(1):74-80.

Saygin, Ö., Demirbaş, N. (2018). Türkiye'de kırmızı et tüketimi: sorunlar ve çözüm önerileri. Selcuk J Agr Food Sci, 32(3):567-574, doi: 10.15316/SJAFS.2018.138

Strateji ve Bütçe Başkanlı̆̆1 (SBB) (2019). Onbirinci Kalkınma Planı (2019-2023), https://www.sbb.gov.tr/wp-content/uploads/ 2019/07/OnbirinciKalkinmaPlani.pdf (Erişim: 01.09.2021).

Şen, İ., Şahin, A. (2017). Mersin'de Yaşayan Tüketicilerin Balık Tüketim Tercihlerini Demografik Faktörler Açısından Ele Alan Bir Araştırma. AKÜ İ̈BF Derg, 18(1): 33-46, doi: 10.5578/jeas.48561

Terin, M., Hamamc1, G., Gül, T., Terin, S. (2016). Van ili kentsel alanda hanelerin balık tüketim yapısı ve satın alma davranışlanının belirlenmesi. Ege J Fish Aquat Sci, 33(3): 241-249. doi: 10.12714/egejfas.2016.33.3.08

TİGEM (2020). Hayvancıllk sektör raporu. Tarım İşletmeleri Genel Müdürlüğü, Ankara. https://www.tigem.gov.tr/DosyaGaleriData/Vi ew/a374cc25-acc1-44e8-a546-63b4c8bce146

(Erişim: 29.08.2021)

TOB (2021). Tarım ve Orman Bakanllğı Faaliyet Raporları. Ankara. https://www.tarimorman.gov.tr/Konular/PlanProgram-Ve-Faaliyet-Raporlari/faaliyetraporlar\%c4\%b1 (Erişim: 25.04.2021)

Tosun, D. (2016). Türkiye'de kırmızı et arzının sürdürülebilirliğini etkileyen faktörlerin belirlenmesi üzerine bir araştırma: İzmir ve 
Afyonkarahisar illeri örneği. Ege Üniversitesi Fen Bilimleri Enstitüsü Tarım Ekonomisi Anabilim Dalı, Doktora Tezi, İzmir. 163s.

TÜİK (2020a). Türkiye İstatistik Kurumu. Nüfus ve Demografi Istatistikleri. https://data.tuik.gov.tr/Kategori/GetKategori? $\mathrm{p}=$ nufus-ve-demografi-109\&dil=1 (Erişim tarihi: 01.11.2020).

TÜiK (2020b). Türkiye İstatistik Kurumu. Hayvancilik İstatistikleri. https://data.tuik.gov.tr/Kategori/GetKategori? $\mathrm{p}=$ tarim-111\&dil=1 (Erişim tarihi: 01.11.2020).

TÜİK (2020c). Türkiye İstatistik Kurumu. Hanehalk1 Tüketim Harcamas1 İstatistikleri. https://data.tuik.gov.tr/Kategori/GetKategori? $\mathrm{p}=$ gelir-yasam-tuketim-ve-yoksulluk-107\&dil=1 (Erişim: 05.02.2021).

TÜİK (2021). Türkiye İstatistik Kurumu. Fiyat İstatistikleri.
VeriBilgi.do?tb_id=46\&ust_id=13 (Erişim tarihi: 01.04.2021)

Türkmen, M., Türkmen, A., Duran, K. (2016). Giresun ilinde balık tüketiminin araştırılması. Türk J Agric Food Sci Tech, 4(8):712-718.

Yağmur, C., Güneş, E. (2010). Dengeli beslenme açısından Türkiye'de gida üretimi ve tüketiminin irdelenmesi. VII. Zirrat Mühendisliği Teknik Kongresi, Ankara, Türkiye. https://www.zmo.org.tr/resimler/ekler/95f1538 4c2a79ce_ek.pdf (Erişim: 30.08.2021)

Yılmaz, İ., Yılmaz, E. (2012). Türkiye'de hayvansal gida tüketimi ve sorunlar. 10. Ulusal Tarım Ekonomisi Kongresi, 5-7 Eylül 2012, Konya, Türkiye, 1293 s. 